\title{
Stigma receptivity, mode of reproduction, and mating system in Mesosetum chaseae Luces (Poaceae), a native grass of the Brazilian Pantanal
}

\author{
L.A.C. Silva ${ }^{1}$, M.S. Pagliarini ${ }^{1}$, S.A. Santos ${ }^{2}$ and C.B. Valle ${ }^{3}$ \\ ${ }^{1}$ Departamento de Biologia Celular e Genética, \\ Universidade Estadual de Maringá, Maringá, PR, Brasil \\ ${ }^{2}$ Embrapa Pantanal, Corumbá, MS, Brasil \\ ${ }^{3}$ Embrapa Gado de Corte, Campo Grande, MS, Brasil \\ Corresponding author: M.S. Pagliarini \\ E-mail: mspagliarini@uem.br
}

Genet. Mol. Res. 12 (4): 5038-5045 (2013)

Received March 4, 2013

Accepted August 20, 2013

Published October 25, 2013

DOI http://dx.doi.org/10.4238/2013.October.25.2

\begin{abstract}
Mesosetum chaseae Luces, known regionally as "grama-do-cerrado", is abundant in the Pantanal region in Brazil and contributes significantly to livestock and environmental conservation. This species is under basic studies at Embrapa Pantanal (Nhecolândia subregion, Pantanal, Corumbá, MS, Brazil). In this study, we present data about stigma receptivity, mode of reproduction, and mating system for 10 accessions collected in Nhecolândia subregion (Pantanal). Stigma receptivity was optimal, producing innumerous oxygen bubbles upon testing with hydrogen peroxidase. Clarified ovaries analyzed under interference microscopy showed an embryo sac of the Polygonum type, typical of sexual species. The mating system, tested in protected flowers, indicated allogamy. These data are important for subsidizing future breeding programs for this species.
\end{abstract}

Key words: Mesosetum chaseae; "Grama-do-cerrado"; Forage; Stigma receptivity; Mode of reproduction; Mating system 


\section{INTRODUCTION}

Mesosetum is a primarily South American genus organized into finer groupings including 42 species. Mesosetum chaseae Luces is a perennial species of 25 to $65 \mathrm{~cm}$ in length, with elongated rhizomes and stolons; erect culms; inflorescences composed of a single unilateral raceme, 3 to $9 \mathrm{~cm}$ long; spikelets solitary with a basal sterile floret (male) and a fertile floret; flowers with three purple anthers; and fruit forming a caryopsis. The largest number of species occurs on the open sandy savannas of northeastern Brazil (Swallen, 1937).

M. chaseae, native to the floodplains of Pantanal, has great economic and environmental importance in the Nhecolândia and Paiaguás subregions. This species, known as "grama-do-cerrado", is highly tolerant of drought and poor soils (Santos et al., 2004) and is highly palatable to cattle in the dry season (Santos et al., 2002). Some basic biological studies are under way with this species to subsidize future breeding programs.

Knowledge of the patterns of flower maturation, timing of pollen release, and female receptivity is important in understanding the breeding system of flowering plants. According to Galen and Plowright (1987), we cannot analyze the consequences of female receptivity schedules unless we have accurate methods of estimating the onset and advance of receptivity over the course of anthesis.

Success in breeding experiments or artificial pollination procedures depends upon important information, such as the timing and duration of the stigma's receptivity (Dafni and Maués, 1998), which can vary from a few hours up to 10 days (Dafni, 1992; Shivanna, 2003). Stigma receptivity can be determined by morphological changes, pollen germination, and staining or testing for enzymatic activity. According to Lankinen et al. (2007), to increase our knowledge about the mode of reproduction and mating system evolution, it is advisable to understand the relationship between specific floral traits and the mating system. The aim of this study was to increase the knowledge about stigma receptivity, mode of reproduction, and mating system in M. chaseae in order to plan future steps towards the breeding of this species. A total of 10 accessions of this species, available in the germplasm collection at Embrapa Pantanal (Corumbá, MS, Brazil), were analyzed to accomplish such purposes.

\section{MATERIAL AND METHODS}

\section{Material}

The 10 accessions of $M$. chaseae analyzed were collected in distinct places in the Nhecolândia subregion (Pantanal), and constitute part of the germplasm collection at Embrapa Pantanal (Nhumirim Farm, Nhecolândia subregion, Pantanal, Corumbá, Mato Grosso do Sul, Brazil). Table 1 indicates the places of collection according to the universal transverse mercator system. Figure 1 illustrates the aspects of M. chaseae under natural field conditions.

\section{Stigma receptivity}

To evaluate stigma receptivity, racemes were collected during anthesis, from 7:00 to 10:00 am, and maintained under hydration until analyses. A total of 50 pairs of stigmas (50 flowers) from different plants were evaluated. The ovaries with the stigmas (female reproduc- 
tive apparatus) were removed from the flowers under stereomicroscopy and placed on a glass slide in a drop of $3 \%$ hydrogen peroxidase and covered with a cover slip, according to the methodology proposed by Zeisler (1938). Stigmas that produced bubbles within 2 to 3 min were considered receptive.

Table 1. Number of accessions in the germplasm collection, place of collection, landscape unit, and collection
point (UTM).
\begin{tabular}{llll}
\hline Accession No. & Place of collection & Phytophysionomy & UTM $^{*}$ \\
\hline 1 & Nhumirim Farm & Non flooded open grassland \\
2 & Nhumirim Farm & Flooded open grassland & $540089 / 7898986$ \\
3 & Nhumirim Farm & Non flooding open grassland & $538171 / 7897724$ \\
4 & Campo Dora Farm & Flooded open grassland & $535406 / 7899592$ \\
5 & Chatelodo Farm & Non flooded open grassland & $533485 / 7901107$ \\
6 & Chatelodo Farm & Non flooded open grassland & $534401 / 7890612$ \\
7 & Chatelodo Farm & Non flooded savanna & $534641 / 7893824$ \\
8 & Valdir's Field Farm & Non flooded savanna & $534754 / 7895118$ \\
9 & Valdir's Field Farm & Babaçu's Forest edge & $540493 / 7906116$ \\
24 & Nhumirim Farm & Non flooded open grassland & $540452 / 7906193$ \\
$*$ *UTM = Universal Transversal Marcator System. & & $539319 / 7902000$ \\
\hline
\end{tabular}

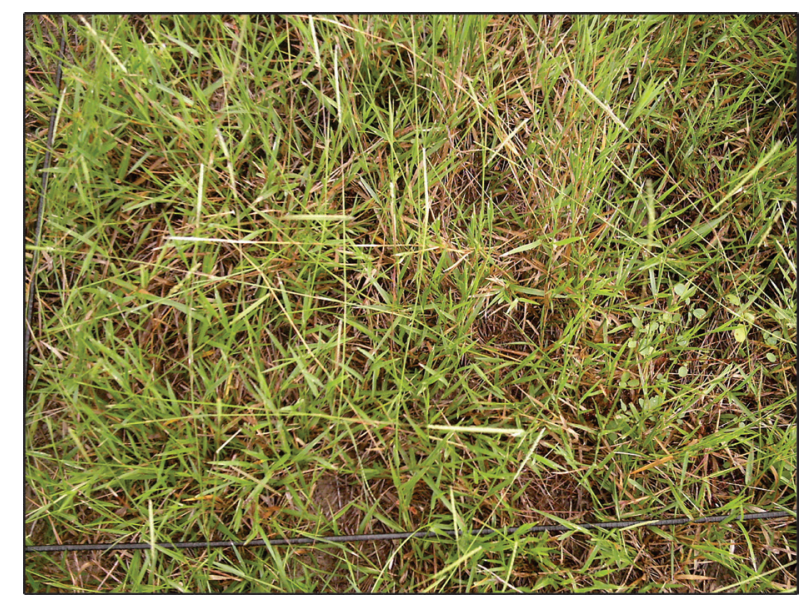

Figure 1. Aspects of Mesosetum chaseae in natural field, showing dominance in the association with other native species.

\section{Mode of reproduction}

The mode of reproduction of the accessions was evaluated through the analyses of the female reproductive apparatus. Embryo sacs were clarified by methyl salicylate according to the methodology proposed by Young et al. (1979) and analyzed under interference contrast microscopy. The central cell was evidenced with $2 \%$ Lugol solution due to the presence of starch granules.

\section{Mating system}

To evaluate the mating system, plants of $M$. chaseae were cultivated in pots in the green- 
house. The racemes were protected with a plastic bag before anthesis to avoid cross-pollination. After 28 days, the racemes were collected and the spikelets were individually analyzed to check for seed formation. Figure 2 illustrates plants in the greenhouse with protected racemes.

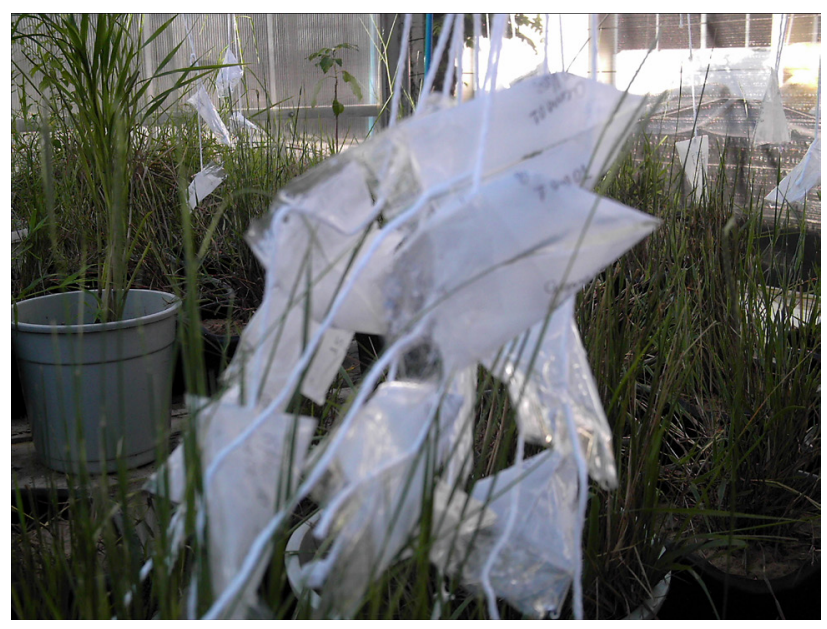

Figure 2. Plants of Mesosetum chaseae with protected flowers in the greenhouse.

\section{RESULTS AND DISCUSSION}

\section{Stigma receptivity}

In the 50 flowers of the 10 accessions analyzed, stigmas were fully receptive. Figure 3 illustrates a female reproductive apparatus (stigma, style, and ovary). Innumerous oxygen bubbles were observed in the stigmas.

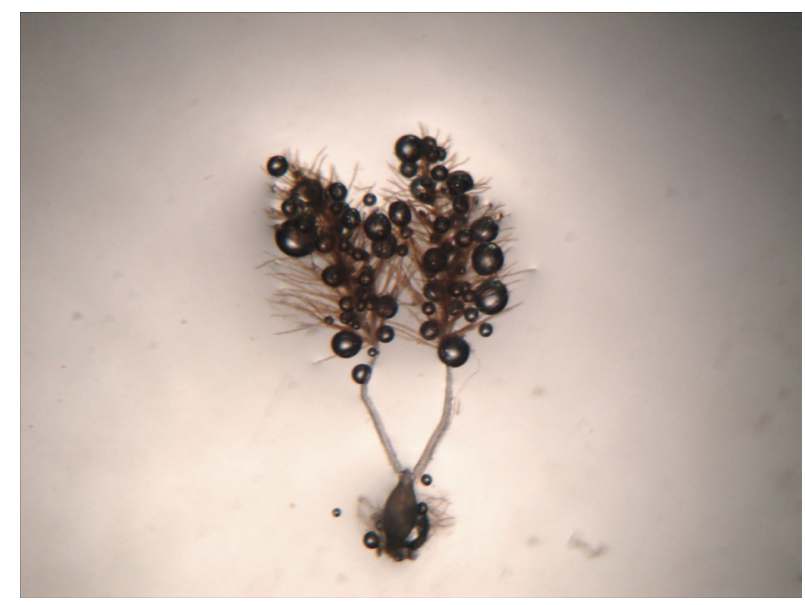

Figure 3. Female reproductive apparatus of Mesosetum chaseae with innumerous bubbles of oxygen in the stigmas after reaction with hydrogen peroxidase. 
Details of stigma receptivity have been studied in only a limited number of species (Shivanna, 2003). There are no satisfactory precise methods to determine stigma receptivity. As receptive stigmas invariably show the presence of several enzymes such as esterases, peroxidases, and acid phosphatases, their presence on the stigma surface has often been considered to indicate receptivity (Dafni, 1992; Dafni and Maués, 1998). It is necessary to consider that although receptive stigmas invariably show the activity of many enzymes, this does not necessarily reflect receptivity, since the surface enzymes in many species appear before the stigma accepts pollen germination (Shivanna and Sastri, 1981). According to Shivanna (2003), the only definite method to study stigma receptivity is through controlled pollination and subsequent studies on effective pollen germination until fruit- and seed-set.

Stigma receptivity and pollen viability are critical for effective initiation of pollenpistil interaction (Shivanna, 2003). According to Dafni (1992), stigma receptivity could be studied for the following purposes: 1 ) to identify the optimum flower age for artificial pollination procedures; 2) in studies of pollination efficiency, since transfer of pollen to pre- or postreceptive stigmas is a waste of pollen; 3 ) for studies of possible interference between the male and female functions and pollen/stigma incompatibility; 4) for studies of breeding systems; and 5) to determine the relative effectiveness of pollinator visits made to flowers during the different stages of anthesis.

\section{Embryo sac and mode of reproduction}

The clarified ovaries of $M$. chaseae showed the presence of an embryo sac typical of angiosperms (Polygonum type); that is, with eight cells (three antipodals, two synergids, one egg cell, and two polar nuclei that will be fused to form a central cell) (Maheshwari, 1978; Batygina, 2002; Yang et al., 2010). This embryo sac is also characteristic of sexual grasses (Greenham and Chapman, 1990). Figure 4 illustrates some aspects of the ovary and the embryo sac of M. chaseae. The synergids and the egg cell were difficult to visualize (Figure 4A), whereas the central cell (Figure 4B) and the antipodals were easily identified (Figure 4C). Synergids are often not easily seen when using methyl salicylate as the clarifying technique, since they are short lived and display little contrast. The egg apparatus, however, is usually differentiated from the other cells by its dense cytoplasm, displaying a granulated appearance. This was not the case with $M$. chaseae, perhaps due to the starchy nature of the central cell. The central cell, when clarified and visualized under microscopy, presented a great amount of plastids (Figure 5A) that became dark when stained with Lugol solution (Figure 5B), denoting the presence of starch granules inside them.

The central cell is the largest cell of the embryo sac and is intimately associated with the antipodal cells on one end and the egg cell apparatus on the other. This cell presents a large vacuole in the center surrounded by a thin peripheral cytoplasm. The cytoplasm around the egg apparatus is dense and contains the polar nucleus (Kapil and Bhatnagar, 1981). In several species, including M. chaseae, the central cell is rich in plastids containing starch grains (amyloplasts). The rapid formation of starch in the central cell at the time of anthesis seems to be a preparation for the oncoming phase of differentiation. The voluminous central cell is an important site for the storage of food reserves. The cytochemical composition of the central cell shows that, in contrast to the egg, it is not only characterized by a high rate of metabolic activity, but also contains adequate food reserves for utilization during fertilization 
and initial growth of the endosperm (Bhatnagar and Johri, 1972; Kapil and Bhatnagar, 1981; Greenham and Chapman, 1990; Batygina, 2002).

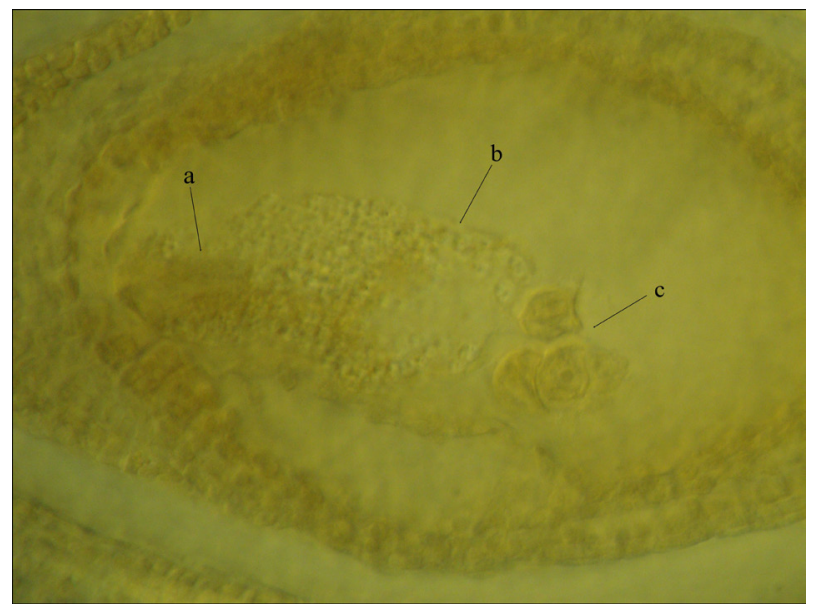

Figure 4. Aspects of the embryo sac showing the egg apparatus (a), the central cell (b), and the three antipodal cells (c).

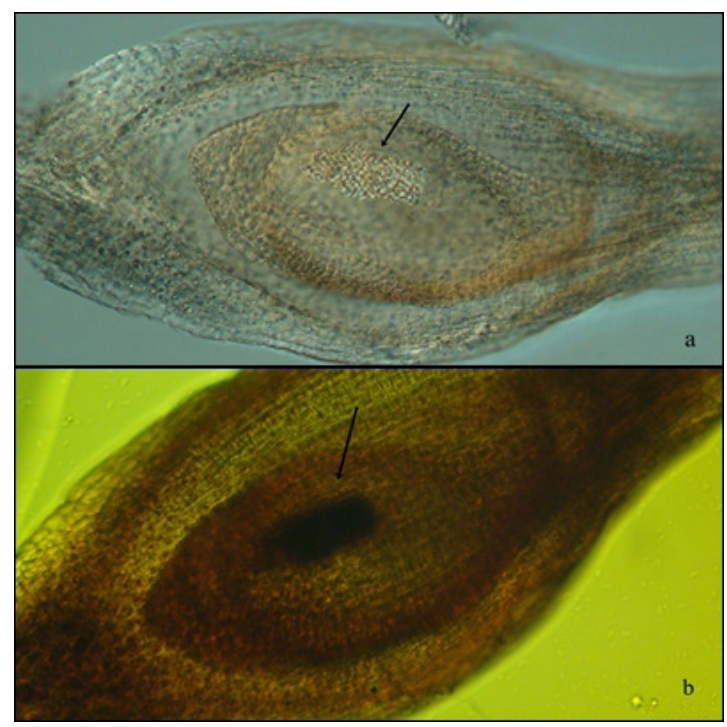

Figure 5. Embryo sacs evidencing the central with plastids (a) and the same cell under lugol staining (b).

During the double fertilization, one generative nucleus of the pollen grain will join with the egg nucleus to form the embryo, while the other generative nucleus will fuse with the two polar nuclei from the central cell to form the $3 n$ endosperm, typical of the sexual species of angiosperms. Through examination of at least 50 ovaries of each accession of $M$. chaseae studied, we concluded that this species has sexual reproduction, since only Polygonum-type embryo sacs were detected and there were no indications of apomixis being present. 


\section{Mating system}

A total of 1100 spikelets removed from 55 protected racemes obtained from the 10 accessions were analyzed. Seeds were not found in any of them. The absence of seed formation in the bagged flowers indicates allogamy (Pinto, 1995). Allogamous plants generally store high heterozygosis and are able to maintain genetic variability through cross-pollination. Although heterozygosis and allogamy create a high flexibility of adaptation, natural selection tends to preserve extensive areas in chromosomes (genes) free of recombination (Grant, 1958). M. chaseae presented predominantly terminal chiasmata (Silva et al., 2012), which prevent interstitial chromosome recombination and thus preserve the genotypic make-up of the accessions.

The information obtained by the study of these accessions indicates that breeding of M. chaseae should follow strategies for allogamous species, including hybridization between accessions to introgress genes of favorable agronomic traits, followed by intrapopulation selection. A wide germplasm collection should be assembled before embarking on a comprehensive breeding program, to ensure that the natural variability of this species is well represented when selecting parental genotypes to be crossed.

\section{ACKNOWLEDGMENTS}

Research supported by Embrapa, CNPq, and Fundação Araucária.

\section{REFERENCES}

Bhatnagar ST and Johri BM (1972). Development of Seed Angiosperm. In: Seed Biology: Importance, Development and Germination. (Kozlowski TT, ed.). Academic Press, New York.

Batygina TB (2002). Embryology of Flowering Plants: Terminology and Concepts. Vol. 1. Generative Organs of Flower. Science Publishers Inc., Enfield.

Dafni A (1992). Pollination Ecology: a Practical Approach. University Press, Oxford.

Dafni A and Maués MM (1998). A rapid and simple procedure to determine stigma receptivity. Sex. Plant Reprod. 11: 177-180.

Galen C and Plowright RC (1987). Testing the accuracy of using peroxidase activity to indicate stigma receptivity. Can. J. Bot. 65: 107-111.

Grant V (1958). The regulation of recombination in plants. Cold Spring Harb. Symp. Quant. Biol. 23: 337-363.

Greenham J and Chapman GP (1990). Ovule Structure and Diversity. In: Reproductive Versatility in the Grasses. (Chapman GP, ed.). Cambridge University Press, Cambridge.

Kapil RN and Bhatnagar AK (1981). Ultrastructure and biology of female gametophyte in flowering plants. Int. Rev. Cytol. 70: 291-341.

Lankinen A, Armbruster WS and Antonsen L (2007). Delayed stigma receptivity in Collinsia heterophylla (Plantaginaceae): genetic variation and adaptive significance in relation to pollen competition, delayed self-pollination, and matingsystem evolution. Am. J. Bot. 94: 1183-1192.

Maheshwari P (1978). An Introduction to the Embryology of Angiosperms. McGraw-Hill Book Company, New York.

Pinto RJB (1995). Introducão ao Melhoramento de Plantas. EDUEM, Maringá.

Santos AS, Costa C, Souza GS, Pott A, et al. (2002). Identificação da composição botânica da dieta de bovinos criados em pastagens nativas na sub-região da Nhecolândia, Pantanal, Brasil. Rev. Bras. Zoot. 31: 1648-1662.

Santos AS, Abreu UGP, Comastri Filho JA and Crispim SMA (2004). Recursos genéticos de gramíneas forrageiras para a pecuária. In: Reunião Anual da Sociedade Brasileira de Zootecnia. SBZ/UCDB, Campo Grande, 17-22.

Shivanna KR (2003). Pollen Biology and Technology. Science Publishers, Enfield.

Shivanna KR and Sastri DC (1981). Stigma-surface esterase activity and stigma receptivity in some taxa characterized by wet stigmas. Ann. Bot. 47: 53-64. 
Silva LA, Pagliarini MS, Santos SA, Silva N, et al. (2012). Chromosome number, microsporogenesis, microgametogenesis, and pollen viability in the Brazilian native grass Mesosetum chaseae (Poaceae). Genet. Mol. Res. 11: 4100-4109.

Swallen JR (1937). The grass genus Mesosetum. Brittonia 2: 363-392.

Yang WC, Shi DQ and Chen YH (2010). Female gametophyte development in flowering plants. Annu. Rev. Plant Biol. 61: 89-108.

Young BA, Sherwood RT and Bashaw EC (1979). Cleared-pistyl and thick-sectioning techniques for detecting aposporous apomixis in grasses. Can. J. Bot. 57: 1668-1672.

Zeisler M (1938). Uber die Abgrenzung der Eigentlichen Narbenfläche nut Hilfe von Reaktionen. Beih. zum Bot. Zentralblatta 58: 308-318. 